\title{
HUBUNGAN PARITAS DAN USIA DENGAN PENGGUNAAN KONTRASEPSI HORMONAL DI WILAYAH KERJA PUSKESMAS D4 KETAHUN
}

\author{
The Relationship between Parity and Age with the Use of Hormonal \\ Contraception in Working Area D4 Ketahun Public Health Center
}

\author{
Waytherlis Apriani', Desi Fitriani ${ }^{1,}$ Sri Lukitaningsih ${ }^{1}$ \\ 1Program Studi DIV Kebidanan STIKES Tri Mandiri Sakti Bengkulu \\ Email: iterapriani12@gmail.com
}

\begin{abstract}
ABSTRAK
Masih tingginya penggunaan kontrasepsi hormonal di Wilayah Kerja Puskesmas D 4 Ketahun. Penelitian ini bertujuan untuk mempelajari hubungan paritas dan usia dengan penggunaan kontrasepsi hormonal di Wilayah Kerja Puskesmas D4 Ketahun Bengkulu Utara. Jenis Penelitian ini adalah Survey Analitik dengan desain Cross Sectiona. Populasi dalam penelitian ini adalah seluruh akseptor KB Aktif dari Bulan Januari s/d Desember 2017 sebanyak 711 akseptor. Sampel dalam penelitian sebanyak 257 akseptor diambil dengan teknik simplel random sampling. Pengumpulan data penelitian ini menggunakan data sekunder dengan mengisi cheklist. Analisis data penelitian ini menggunakan analisis univariat dan bivariate dengan uji Chi-Square dan Contingenty Coefficient. Hasil penelitian didapatkan: Dari 257 Akseptor KB terdapat 244 Akseptor hormonal, 176 Akseptor multipara, 189 Akseptor usia 20-35 Tahun, Terdapat Ada hubungan antara paritas dengan penggunaan kontrasepsi hormonal di Wilayah Kerja Puskesmas D4 Ketahun dengan kriteria sedang dan terdapat Ada hubungan yang antara usia dengan penggunaan kontrasepsi hormonal di Wilayah Kerja Puskesmas D4 Ketahun dengan kriteria sedang. Diharapkan kepada Puskesmas dapat memberikan pendidikan kesehatan dengan penyuluhan tentang pemilihan alat kontrasepsi yang benar/tepat dan memotivasi akseptor penggunaan kontrasepsi hormonal untuk menjarangkan atau menghentikan kehamilan sebaiknya menggunakan kontrasepsi jangka panjang atau kontrasepsi mantap.
\end{abstract}

Kata Kunci: kontrasepsi hormonal, paritas,umur

\begin{abstract}
The use of hormonal contraception is still high in working area D4 Ketahun Public Health Center. The aim of this study was to learn the relationship between parity and the use of hormonal contraception in working area D4 Ketahun Public Health Center. This type of research was an Analytical Survey with a cross section design. The population in this study was all active family planning acceptors from January to December 2017 totaling 711 acceptors. The total sample in the study was 257 acceptors taken by Simple Random Sampling technique. This research data collection used secondary data by filling in a checklist. Data analysis in this study used univariate and bivariate analysis with Chi-Square test and Contingenty Coefficient. The results were obtained: of 257
\end{abstract}


KB Acceptors, there were 244 hormonal acceptors, 176 multipara acceptors, 189 acceptors aged 20-35 years, There was a relationship between parity and contraceptive hormone use in working area D4 Ketahun Public Health Center with the use of hormonal contraception in working area D4 Ketahun Public Health Center with medium criteria. It was expected that Ketahun Public Health Center can provide health education with a guide on the selection of appropriate contraception and motivate the use of hormonal contraception to spell or reverse the assessment using long-term contraception or steady contraception.

Keywords: age, hormonal contraception, parity

\section{A. Pendahuluan}

Menurut

Organization

penggunaan

meningkat di banyak bagian dunia, terutama di Asia dan Amerika Latin dan terendah di Sub-Sahara Afrika. Secara global, pengguna kontrasepsi modern telah meningkat tidak signifikan dari 54\% pada tahun 1990 menjadi $57,4 \%$ pada tahun 2014. Secara regional, proporsi pasangan usia subur 15-49 tahun melaporkan penggunaan metode kontrasepsi modern telah meningkat minimal 6 tahun terakhir. Di Afrika dari 23,6\% menjadi 27,6\%, di Asia telah meningkat dari $60,9 \%$ menjadi $61,6 \%$, sedangkan Amerika latin dan Karibia naik sedikit dari $66,7 \%$ menjadi $67,0 \%$.

Berdasarkan data Pengguna kontrasepsi di dunia menurut WHO (2014) lebih dari 100 juta wanita menggunakan kontrasepsi hormonal lebih dari $75 \%$ dan $25 \%$ menggunakan non hormonal. Di Indonesia kontrasepsi hormonal merupakan metode kontrasepsi yang paling banyak digunakan, hal ini dapat terlihat berdasarkan jumlah peserta KB aktif di Indonesia tahun 2014 berjumlah $35.202 .908 \quad(74,87 \%), \quad 47,57 \%$ menggunakan kontrasepsi suntik, kontrasepsi pil $(23,58 \%)$ dan implant $(10,46 \%)$ (BKKBN, 2015).

Cakupan peserta KB aktif pasangan usia subur (PUS) di
Indonesia pada tahun 2016 sebesar $74,80 \%$. Tiga provinsi yang memiliki presentasi tertinggi yaitu Maluku Utara sebesar 87,03\%, kepulauan Bangka Belitung sebesar $83,92 \%$ dan Sulewesi Utara sebesar $83,84 \%$. Yang terendah terdapat di Nusa Tenggara Timur sebesar 63,24\%, Sunatera Barat sebesar $63,75 \%$, DKI Jakarta sebesar 67,46\%, sedangkan pencapaian untuk provinsi Bengkulu sebesar 79,64\% (Kemenkes RI,2015).

Pilihan jenis alat kontrasepsi di indonesia umumnya masih terarah pada kontrasepsi hormonal seperti suntik, pil, implan. Sementara kebijakan KB pemerintah lebih mengarah pada penggunaan kontrasepsi non hormonal seperti MOP, IUD, dan MOW. Anjuran yang disampaikan program didasarkan pada pertimbangan ekonomi penggunaan alat kontrasepsi non hormonal yang dinilai lebih efisien. Efisien yang dimaksud berkaitan dengan ketersediaan anggaran penyediaan kontrasepsi dengan efektifitas, biaya, tingkat kegagalan, efek samping dan kompilasi. Sementara dari sisi medis, alat kontrasepsi non hormonal dinilai lebih aman bagi kesehatan tubuh. Sebaliknya, alat kontrasepsi hormonal selain tidak ekonomis juga sangat berpengaruh terhadap kesehatan dalam jangka waktu panjang. (BKKBN, 2015). Selain faktor umur pemilhan kontrasepsi juga dipengaruhi oleh 
faktor paritas atau jumlah anak. WUS dengan jumlah anak yang lebih banyak akan mempertimbangkan menggunakan metode kontrasepsi jangka panjang. Prioritas utama alat kontrasepsi yang dipakai ibu dengan jumlah paritas lebih dari dua adalah metode kontrasepsi jangka panjang akan tetapi banyak ibu dengan jumlah paritas lebih dari dua masih memilih kontrasepsi seperti suntik/injeksi dan pil KB. Ibu yang mempunyai anak lebih dari dua tidak disarankan untuk memakai kontrasepsi suntik/injeksi dan pil KB, karena angka kegagalannya masih tinggi. (Saifuddin, 2010).

Bedasarkan data Dinas Kesehatan Bengkulu tahun 2017 jumlah peserta KB aktif 256.235 peserta terdiri dari metode MKJP 57.311 peserta $(22,36 \%)$ dengan rincian IUD 12.708 peserta $(4,95 \%)$, MOP 800 peserta $(0,31 \%)$, MOW 5.264 peserta $(2,05 \%)$, implant 38.539 peserta $(15,04 \%)$, metode non MKJP 198.924 peserta $(77,63 \%)$ peserta terdiri dari metode suntik 140.492 pesera $(54,82 \%)$, pil 44.412 peserta $(17,33 \%)$, kondom 14.020 peserta $(5,47 \%)$. Berdasarkan uraian data peserta $\mathrm{KB}$ tersebut terdapat 3 metode $\mathrm{KB}$ yang memiliki presentasi tertinggi yaitu pemakaian $\mathrm{KB}$ suntik mencapai $140.492(54,82 \%)$ peserta, $\mathrm{KB}$ pil 44.412 (17,33\%), implant $38.539 \quad(15,04 \%) \quad$ (Dinkes Provinsi Bengkulu, 2017).

Di Kabupaten Bengkulu Utara jumlah peserta KB aktif tahun 2017 berjumlah 38.515 akseptor terdiri dari penggunaan kontrasepsi KB hormonal berjumlah 33.119 orang (suntik 20.876, pil 6.158, inplant 6.085 ) dan pengguna KB non hormonal berjumlah 5.396 orang (kondom 1.650, IUD 2.037,
MOW 1.535, MOP 1) ( Dinkes Kabupaten Bengkulu Utara, 2017).

Rumusan dalam penelitian ini adalah "Apakah ada Hubungan Paritas dan Usia Dengan Penggunaan Kontrasepsi Hormonal Di Wilayah Kerja Puskesmas D4 Ketahun Bengkulu Utara?" Tujuan Penelitian ini adalah Mempelajari Hubungan Paritas dan Usia Dengan Penggunaan Kontrasepsi Hormonal Di Wilayah Kerja Puskesmas D4 Ketahun Bengkulu Utara.

\section{B. Metode Penelitian}

Penelitian ini telah dilakukan di Puskesmas D4 Ketahun Kecamatan Pinang Raya Bengkulu Utara, pada tanggal 07 Juli - 07 Agustus 2018. Jenis penelitian yang digunakan dalam penelitian ini adalah survey Analitik yang menggunakan pendekatan cross sectional Populasi dalam penelitian ini adalah seluruh akseptor KB Aktif di Wilayah Kerja Puskesmas D4 Ketahun Kecamatan Pinang Raya Bengkulu Utara Januari s/d desember 2017 sebanyak 711 akseptor. Pengambilan sampel dalam penelitian menggunakan tehnik Simple Random Sampling. Sampel dalam penelitian ini berjumlah 257 orang sampel. Teknik Pengumpulan menggunakan data primer dan data sekunder. Data dianalisis secara univariat untuk dan bivariat. Uji statistik yan digunakan adalah Chi-square.

\section{Hasil Penelitian \\ 1. Analisis Univariat}

Analisis univariat bertujuan untuk mengetahui distribusi frekuensi variable terikat (Kontrasepsi Hormonal) dan Variabel bebas (umur dan paritas) Hasil adalah sebagai berikut : 
Tabel 1

Distribusi Frekuensi Penggunaan Alat Kontrasepsi di Wilayah Kerja Puskesmas D4 Ketahun

\begin{tabular}{cccc}
\hline No & Kontrasepsi & Jumlah & Persentase(\%) \\
\hline 1 & Hormonal & 244 & 94,9 \\
2 & Non Hormonal & 13 & 5,1 \\
\hline & Jumlah & 257 & 100,0 \\
\hline
\end{tabular}

Berdasarkan Tabel 1 diketahui kontrasepsi hormonal dan $(5,1 \%)$ bahwa dari 257 sampel terdapat akseptor pengguna kontrasepsi non (94,9\%) akseptor pengguna hormonal.

Tabel 2

Distribusi Frekuensi Paritas Pengguna Kontrasepsi Hormonal di Wilayah Kerja Puskesmas D4 Ketahun

\begin{tabular}{cccc}
\hline No & Paritas & Jumlah & Persentase (\%) \\
\hline 1 & Primipara & 29 & 11,4 \\
2 & Multipara & 176 & 68,5 \\
3 & Grandemulti & 52 & 20,2 \\
\hline & Jumlah & 257 & 100,0 \\
\hline
\end{tabular}

Berdasarkan Tabel 2 diketahui akseptor multipara dan (20,2\%) bahwa dari 257 akseptor terdapat akseptor grandemulti. $(11,4 \%)$ akseptor primipara, $(68,5 \%)$

Tabel 3.

Distribusi Frekuensi Usia Pengguna Kontrasepsi Hormonal di Wilayah Kerja Puskesmas D4 Ketahun

\begin{tabular}{clcc}
\hline No & \multicolumn{1}{c}{ Umur } & Jumlah & Persentase $(\%)$ \\
\hline 1 & $<20$ Tahun & 13 & 5,1 \\
2 & 20 - 35 Tahun & 189 & 73,5 \\
3 & $>$ 35 Tahun & 55 & 21,4 \\
\hline \multicolumn{2}{l}{ Jumlah } & 257 & 100,0 \\
\hline
\end{tabular}

Berdasarkan Tabel 3 diketahui bahwa dari 257 sampel terdapat $(5,1 \%)$ akseptor usia < 20 Tahun, $(73,5 \%)$ akseptor usia 20 - 35 Tahun, $(21,4 \%)$ akseptor usia $>35$ Tahun.

\section{Analisis Bivariat}

Analisis bivariat bertujuan untuk mengetahui hubungan antara variable terikat (Kontrasepsi Hormonal) dan Variabel bebas (umur dan paritas) Hasil adalah sebagai berikut : 
Tabel 4

Tabel Silang Hubungan Paritas Dengan Penggunaan Kontrasepsi Hormonal di Wilayah Kerja Puskesmas D4 Ketahun

\begin{tabular}{|c|c|c|c|c|c|c|c|c|c|}
\hline \multirow[b]{2}{*}{ Paritas } & \multicolumn{4}{|c|}{ Kontrasepsi } & \multirow[b]{2}{*}{ Jumlah } & \multirow[b]{2}{*}{$\%$} & \multirow[b]{2}{*}{$\chi^{2}$} & \multirow[b]{2}{*}{$\mathrm{p}$} & \multirow[b]{2}{*}{$\mathrm{C}$} \\
\hline & Hormol & $\%$ & $\begin{array}{c}\text { Non } \\
\text { Hormonal }\end{array}$ & $\%$ & & & & & \\
\hline Primipara & 28 & 10.9 & 1 & 0.4 & 29 & 11.3 & \multirow{4}{*}{35.596} & \multirow{4}{*}{0,002} & \multirow{4}{*}{0,349} \\
\hline Multipara & 175 & 68.1 & 1 & 0.4 & 176 & 68.5 & & & \\
\hline Grade & 41 & 16.0 & 11 & 4.3 & 52 & 20.2 & & & \\
\hline Jumlah & 244 & 94.9 & 13 & 5.1 & 257 & 100 & & & \\
\hline
\end{tabular}

Berdasarkan Tabel 4 diketahui bahwa akseptor dengan kategori primipara penggunaan kontrasepsi hormonal sebanyak 28 akseptor. kategori primipara penggunaan kontrasepsi non hormonal sebanyak 1 akseptor Katagori multipara penggunaan kontrasepsi hormonal sebanyak 175 akseptor dan Katagori multipara penggunaan kontrasespsi non hormonal sebanyak 1 akseptor. Katagori grademulti penggunaan kontrasespsi hormonal sebanyak 41 akseptor dan Katagori grademulti penggunaan kontrasespsi non hormonal sebanyak 11 akseptor.

Berdasarkan uji Chi square yang dilakukan, diperoleh nilai $\chi^{2}=$ 35.596 dengan $p=0,000<\alpha=0,05$ jadi signifikan, sehingga $\mathrm{H0}$ ditolak dan $\mathrm{Ha}$ diterima, artinya ada hubungan yang signifikan antara paritas dengan penggunaan kontrasepsi hormonal di Wilayah Kerja Puskesmas D4 Ketahun. Hasil uji Contingency Coefficient (CC) sebesar 0.349 dengan $\mathrm{p}=0,000<0,05$ berarti signifikan dan kategori hubungan sedang.

Tabel 5

Tabel Silang Hubungan Usia Dengan Penggunaan Kontrasepsi Hormonal di Wilayah Kerja Puskesmas D4 Ketahun

\begin{tabular}{|c|c|c|c|c|c|c|c|c|c|}
\hline \multirow[b]{2}{*}{ Umur } & \multicolumn{4}{|c|}{ Kontrasepsi } & \multirow{2}{*}{\multicolumn{2}{|c|}{ Jumlah }} & \multirow[b]{2}{*}{$\chi^{2}$} & \multirow[b]{2}{*}{$\mathrm{p}$} & \multirow[b]{2}{*}{$\mathrm{C}$} \\
\hline & Hormonal & $\%$ & $\begin{array}{c}\text { Non } \\
\text { Hormonal }\end{array}$ & $\%$ & & & & & \\
\hline$<20$ & 12 & 4.7 & 1 & 0.4 & 13 & 5.1 & \multirow{4}{*}{26.209} & \multirow{4}{*}{0,000} & \multirow{4}{*}{0.304} \\
\hline $20-35$ & 187 & 73.5 & 2 & 0.8 & 189 & 73.5 & & & \\
\hline$>35$ & 45 & 17.5 & 10 & 3.9 & 55 & 21.4 & & & \\
\hline Jumlah & 244 & 94.9 & 13 & 5.1 & 257 & 100 & & & \\
\hline
\end{tabular}

Berdasarkan Tabel 5 diketahui bahwa akseptor dengan kategori umur $<20$ Tahun penggunaan kontrasespsi hormonal sebanyak 12 akseptor, kategori umur < 20 Tahun penggunaan kontrasespsi non hormonal sebanyak 1 akseptor. Kategori umur 20 - 35 Tahun penggunaan kontrasepsi hormonal sebanyak 187 akseptor, kategori umur 20 - 35 Tahun penggunaan kontrasepsi non hormonal sebanyak 2 akseptor, kategori umur $>35$ Tahun penggunaan kontrasespsi hormonal sebanyak 45 akseptor dan kategori umur > 35 Tahun penggunaan kontrasepsi non hormonal sebanyak 13 akseptor.

Berdasarkan uji Chi square yang dilakukan, diperoleh nilai $\chi^{2}=$ 26.209 dengan $p=0,000<\alpha=0,05$ jadi signifikan, sehingga $\mathrm{HO}$ ditolak dan $\mathrm{Ha}$ diterima, artinya ada hubungan yang signifikan antara usia dengan 
penggunaan kontrasepsi hormonal di Wilayah Kerja Puskesmas D4 Ketahun. Hasil uji Contingency Coefficient (CC) sebesar 0.304 dengan $\mathrm{p}=0,000<0,05$ berarti signifikan dan kategori hubungan sedang.

\section{Pembahasan}

Hasil penelitian menunjukan bahwa dari 257 akseptor, terdapat akseptor menggunakan kontrasepsi hormonal $(94,9 \%)$ dan akseptor menggunakan kontrasepsi non hormonal $(5,1 \%)$. Kontrasepsi hormonal yang di gunakan meliputi suntik KB (89\%), pil KB (3,50\%) dan inplant $\quad(2.33 \%)$ Sedangkan kontrasepsi non hormonal meliputi IUD (3.11), MOW (1,16\%) dan kondom $(0.78 \%)$.

Sebagian besar akseptor menggunakan kontrasepsi hormonal sebab metode ini dapat diandalkan dan dengan mudah dapat kembali subur, familiar dan dikarenakan akseptor kurang mengetahui dan memahami alat kontrasepsi apa yang sesuai dengan umur dan paritas / jumlah anak yang mereka miliki dan dampak yang akan timbul atau komplikasi yang akan ditimbulkan dengan penggunaan alat kontrasepsi hormonal.

Hasil penelitian menunjukan bahwa dari 257 akseptor, terdapat akseptor dengan jumlah anak 2-3 orang (multipara) $(68,5 \%)$, akseptor dengan jumlah anak $\leq 4$ (grandemulti) $(20,2 \%)$ dan akseptor dengan jumlah anak 1 orang (primipara) (11,3\%). Hasil penelitian ini menunjukan akseptor paritas primipara menggunakan kontrasepsi hormonal sebanyak $(96,5 \%)$, paritas multipara sebanyak $(99,4 \%)$ dan grandemulti sebanyak $(78,8 \%)$.

Hasil penelitian menunjukan bahwa dari 257 akseptor, terdapat akseptor berumur $20-35$ Tahun
$(73,5 \%)$, akseptor berumur $>35$ Tahun $(21,4 \%)$ dan akseptor berumur $<20$ Tahun $(5,1 \%)$. Berdasarkan hasil penelitan ini akseptor dengan umur < 20 Tahun menggunakan kontrasepsi hormonal sebanyak (92.3\%), umur 20 35 Tahun menggunakan kontrasepsi hormonal sebanyak $(98,9 \%)$ dan usia >35 Tahun menggunakan kontrasepsi hormonal sebanyak $(81,8 \%)$.

Berdasarkan hasil uji chi-square diperoleh $p$ value sebesar $0,000<0,05$, sehingga Ha diterima dan Ho ditolak. Hal ini berarti ada hubungan antara paritas dengan penggunaan kontrasepsi hormonal di Wilayah Kerja Puskesmas D4 Ketahun.

Hasil penelitian ini menunjukan dari 29 akseptor primipara 28 akseptor menggunakan kontrasepsi hormonal dan dari 176 akseptor multipara 175 akseptor juga menggunakan kontrasepsi hormonal, hal ini dikarenakan dengan menggunakan kontrasepsi hormonal akseptor dapat menjarangkan, menunda kehamilan dan merencanakan kehamilan berikutnya.

Dari 52 akseptor grandemulti 41 akseptor menggunakan kontrasepsi hormonal, tingginya penggunaan kontrasepsi hormonal pada grandemulti ini dikarenakan akseptor beranggapan bahwa kontrasepsi hormonal lebih murah, mudah dijangkau oleh akseptor dan praktis. Hal ini menunjukkan bahwa akseptor lebih memilih alat kontrasepsi hormonal yang mempunyai murah, mudah, praktis dan mempunyai keefektifitasan yang tinggi meskipun alat kontrasepsi itu tidak sesuai dengan usia dan paritas mereka saat ini.

Hasil penelitian ini sejalan dengan penelitian Suherman (2017) Pada penelitian ini didapatkan hubungan yang bermakna antara paritas dan pemilihan jenis metode kontrasepsi yang digunakan di Kecamatan Argapura, Kabupaten Majalengka. 
Sebagian besar akseptor yang mengunakan metode kontrasepsi hormonal (suntik) 2.354 orang dari 3.228 dan memiliki paritas $2-3$ orang anak dengan hasil $72,9 \%$.

Hal tersebut sebanding dengan penelitian yang dilakukan oleh Dahliana (2013) yang memperlihatkan terdapat hubungan antara paritas dan penggunaan metode kontrasepsi hormonal (suntik). Tingginya minat memakai suntik KB dikarenakan metode kontrasepsi suntik sangat efektif, murah, aman, dan merupakan alat kontrasepsi dengan pencegahan kehamilan jangka panjang sehinga metode tersebut banyak diminati oleh ibu.

Pada penelitian ini, diperoleh bahwa paritas multipara paling banyak memilih kontrasepsi hormonal. Hal ini sesuai dengan teori yang mengatakan seseorang dalam memutuskan untuk mengikuti program KB adalah apabila merasa bahwa banyaknya anak yang masih hidup sudah mencukupi jumlah yang diinginkan. Berarti banyaknya anak yang masih hidup mempengaruhi kesertaan seseorang dalam mengikuti program KB. Semakin besar jumlah anak hidup yang dimiliki seseorang, semakin besar kemungkinan untuk membatasi kelahiran. Dengan melihat jumlah anak yang dilahirkan hidup di temukan pula hubungan yang bersifat positif, artinya makin tua umur mencerminkan proses perubahan keluarga dan dapat juga memperlihatkan proses perubahan fertilitas antar waktu (Kemenkes RI, 2015).

Semakin besar jumlah anak hidup yang dimiliki seseorang, semakin besar kemungkinan untuk membatasi kelahiran. Jumlah banyak anak disini apabila jumlah anaknya lebih dari 4 (grandemulti) jumlah anak sedang antara 2-3 (multipara). dan jumlah anak kurang dari 2 (primipara). Jumlah anak hidup memberikan pengaruh yang sangat bermakna dalam menentukan pemilihan alat kontrasepsi jangka panjang (Handayani, 2010).

Dalam penelitian ini ditemukan 1 akseptor primipara dan 1 akseptor multipara menggunakan kontrasepsi non hormonal yaitu kondom hal ini dikarenakan akseptor tersebut tidak cocok menggunakan kontrasepsi hormonal seperti pil, suntik dan susuk $\mathrm{KB}$, bila menggunakan kontrasepsi tersebut akseptor mengalami menstrusai terus-menerus dan 11 akseptor grandemulti menggunakan kontrasepsi non hormonal yaitu IUD dan MOW.

Dari hasil analisis Contingency Coefficient $(C)$ diperoleh nilai 0,349 yang menunjukkan bahwa hubungan antara paritas dengan penggunaan kontrasepsi hormonal dalam kategori sedang.

Berdasarkan uji chi-square diperoleh $p$ value sebesar $0,000<0,05$ sehingga Ha diterima dan Ho ditolak. Hal ini berarti ada hubungan antara umur dengan penggunaan kontrasepsi hormonal di Wilayah Kerja Puskesmas D4 Ketahun.

Hasil penelitian ini menunjukan dari 13 akseptor umur < 20 Tahun, 12 akseptor menggunakan kontrasepsi hormonal, dari 189 akseptor umur 2035 Tahun, 187 akseptor menggunakan kontrasepsi hormonal dan dari 55 akseptor umur $>35$ Tahun, 45 akseptor juga menggunakan kontrasepsi hormonal. Hasil penelitian ini sesuai dengan hasil penelitian Arliana, Sarake, \& Seweng, (2013) dengan hasil uji Chi Square, $(\mathrm{p}=0,004<0.005)$ menunjukan adanya hubungan antara umur ibu sekarang dengan penggunaan kontrasepsi hormonal. Adanya hubungan antara umur ibu sekarang dengan penggunaan metode 
kontrasepsi hormonal pada akseptor $\mathrm{KB}$ diasumsikan bahwa akseptor KB telah mengetahui pola penggunaan kontrasepsi yang rasional yaitu pemilihan kontrasepsi disesuaikan dengan fase umur. Penelitian ini sejalan dengan penelitian yang dilakukan oleh Tunnisa (2010) di Soppeng dan Zainuddin (2012) di Pangkep yang menemukan adanya hubungan antara umur ibu dengan penggunaan kontrasepsi hormonal. Usia sangat berpengaruh dalam mengatur jumlah anak yang dilahirkan. Usia kurang dari 20 Tahun merupakan usia sangat beresiko apabila terjadi kehamilan baik bagi ibu dan bayi, sangat diperlukan kontrasepsi yang efektif untuk menunda kehamilan sampai usia benarbenar matang untuk kehamilan. Periode usia 20-35 tahun adalah periode menjarangkan kehamilan untuk itu diperlukan metode kontrasepsi yang efektivitasnya cukup tinggi, jangka waktunya lama (2-4 tahun) dan reversibel. Prioritas kontrasepsi yang sesuai yaitu AKDR, Suntikan, Mini pil, Pil, cara sederhana, Norplant (AKBK) dan Kontap. Usia lebih dari 35 tahun merupakan fase menghentikan kehamilan sehingga dibutuhkan kontrasepsi dengan kriteria yang lebih tinggi yaitu efektivitas sangat tinggi dan tidak menambah kelainan / penyakit yang sudah ada (Kemenkes RI, 2015).

Berdasarkan pendapat diatas dapat disimpulkan bahwa usia mempunyai hubungan yang positif dengan pemilihan jenis alat kontrasepsi dimana seiring tingginya tingkat kematangan sistem reproduksi atau usia ibu akan diikuti kenaikkan dalam pemilihan jenis metode kontrasepsi jangka panjang.

Dalam penelitian ini juga ditemukan 1 akseptor usia $<20$ tahun menggunakan kontrasepsi non hormonal yaitu kondom, 2 akseptor usia 20-35 Tahun menggunakan kontrasepsi non hormonal yaitu kondom dan IUD dan 10 akseptor usia >35 Tahun menggunakan kontrasepsi non hormonal yaitu IUD dan MOW.

Dari hasil analisis Contingency Coefficient $(C)$ diperoleh nilai 0,304 hal ini menunjukkan bahwa hubungan antara umur dengan penggunaan kontrasepsi hormonal termasuk dalam kategori sedang.

\section{E. Kesimpulan}

1. Dari 257 Akseptor terdapat 244 $(94,9 \%)$ orang pengguna kontrasepsi hormonal

2. Dari 257 Akseptor terdapat 176 $(68,5 \%)$ orang multipara

3. Dari 257 Akseptor terdapat 176 $(73,5 \%)$ orang usia 20 - 35 Tahun.

4. Ada hubungan yang signifikan antara paritas dengan penggunaan kontrasepsi hormonal di Wilayah Kerja Puskesmas D4 Ketahun dengan kategori sedang.

5. Ada hubungan yang signifikan antara usia dengan penggunaan kontrasepsi hormonal di Wilayah Kerja Puskesmas D4 Ketahun dengan kategori sedang.

\section{Daftar Pustaka}

Arliana, W. O. D., Sarake, M., \& Seweng, A. (2013). Faktor yang berhubungan dengan Penggunaan Metode Kontrasepsi Hormonal pada Akseptor KB di Kelurahan Pasarwajo Kecamatan Pasarwajo Kabupaten Buton Sulawesi Tenggara. Diunduh dari

http://www.ejournal.repository. unhas.ac.id

BKKBN. (2015). Perhitungan Alkon Program KKBPK. Diaskes pada 
tanggal tanggal 6 Februari 2018.

Dahliana. (2013). Hubungan Antara Paritas Dan Status Ekonomi Keluarga Dengan Pemakaian Kontrasepsi Suntik Di Rumah Bersalin Citra Palembang Tahun 2013. Diunduh dari https://www.scribd.com/docum ent/233468031/Hubungan-

Antara-Paritas-Ibu-Dan-StatusEkonomi-Keluarga-DenganPemakaian-Kontrasepsi-SuntikDi-Rumah-Bersalin-CitraPalembang-Tahun-2013

Dinkes Provinsi Bengkulu. (2017) Profil Dinas Kesehatan Provinsi Bengkulu Tahun 2017. Bengkulu:Dinkes Provinsi Bengkulu

Dinkes Bengkulu Utara. (2017) . Profil Kesehatan Kabupaten Bengkulu Utara 2017. Argamakmur: Dinas Bengkulu Utara.

Hanafi, H. (2012). Keluarga Berencana dan Kontrasepsi. Jakarta: Pustaka Sinar Harapan

Handayani. (2010). Pelayanan Keluarga Berencana. Yogyakarta: Pustaka Rihanna Kemenkes RI. (2015). Profil Kesehatan Indonesia Tahun 2014. Jakarta: Kemenkes RI.

Suherman, R. M. (2017) Hubungan Karakteristik Akseptor dengan Pemilihan Metode Kontrasepsi
(Studi di Kecamatan Argapura, Kabupaten Majalengka) Di Unduh dari https://proceeding.unisba.ac.id Saifuddin, A. B. (2010). Buku Panduan Praktis Pelayanan Kontrasepsi. Jakarta : Penerbit Yayasan Bina Pustaka.

Tunnisa, R. (2010). Faktor-Faktor yang Berhubungan dengan Pemilihan Alat Kontrasepsi di Wilayah Kerja Puskesmas Takalala Kecamatan Marioriwawo Kecamatan Soppeng Tahun 2010. Skripsi. Fakultas Kesehatan Masyarakat Universitas Hasanuddin, Makassar. Diunduh dari https://repository.unhas.ac.id

WHO. (2014). Medical Eligibility Criteria For Contraceptive Use. Geneva: Department of Reproduction and Research World Health Organization.

Zainuddin, E. (2012). Faktor yang Berhubungan dengan Pemilihan Metode Kontrasepsi Efektif Terpilih (MKET) Pada Akseptor KB di Kelurahan Tonasa Kecamatan Balocci Kabupaten Pangkep Tahun 2012. Diunduh dari https://repository.unhas.ac.id. 